\title{
MILD HYPOTHERMIA REDUCES POLYMORPHONUCLEAR LEUKOCYTES INFILTRATION IN INDUCED BRAIN INFLAMMATION
}

\author{
Mirto N. Prandini', Antonio Neves Filho², Antonio J. Lapa³, João N. Stavale ${ }^{4}$
}

\begin{abstract}
Over the last 50 years deep hypothermia $\left(23^{\circ} \mathrm{C}\right)$ has demonstrated to be an excellent neuroprotective agent in cerebral ischemic injury. Mild hypothermia $\left(31-33^{\circ} \mathrm{C}\right)$ has proven to have the same neuroprotective properties without the detrimental effects of deep hypothermia. Mechanisms of injury that are exaggerated by moderate hyperthermia and ameliorated by hypothermia include, reduction of oxygen radical production, with peroxidase damage to lipids, proteins and DNA, microglial activation and ischemic depolarization, decrease in cerebral metabolic demand for oxygen and reduction of glycerin and excitatory amino acid (EAA) release. Studies have demonstrated that inflammation potentiates cerebral ischemic injury and that hypothermia can reduce neutrophil infiltration in ischemic regions. To further elucidate the mechanisms by which mild hypothermia produces neuroprotection in ischemia by attenuating the inflammatory response, we provoked inflammatory reaction, in brains of rats, dropping a substance that provokes a heavy inflammatory reaction. Two groups of ten animals underwent the same surgical procedure: the skull bone was partially removed, the duramater was opened and an inflammatory substance ( $5 \%$ carrageenin) was topically dropped. The scalp was sutured and, for the group that underwent neuroprotection, an ice bag was placed covering the entire skull surface, in order to maintain the brain temperature between 29,5$31^{\circ} \mathrm{C}$ during 120 minutes. After three days the animals were sacrificed and their brains were examined. The $\mathrm{g}$ roup protected by hypothermia demonstrated a remarkable reduction of polymorphonuclear leukocytes (PMNL) infiltration, indicating that mild hypothermia can have neuro p rotective effects by reducing the inflammatory reaction.
\end{abstract}

KEY WORDS: cerebral hypothermia, brain protection, brain inflammation, hypothermia.

\section{A hipotermia moderada reduz a infiltração leucocitária na inflamação encefálica induzida}

RESUMO - Nos últimos 50 anos, a hipotermia tem demonstrado ser um excelente agente neuroprotetor nas lesões isquêmicas encefálicas. A hipotermia moderada $\left(31^{\circ} \mathrm{C}-33^{\circ} \mathrm{C}\right)$ provou também apresentar as mesmas propriedades protetoras, sem os efeitos deletérios da hipotermia profunda. Dentre alguns mecanismos de lesão que são melhorados pela hipotermia e piorados pela hipertermia moderada, podemos citar a diminuição da demanda de oxigênio pelo encéfalo e a redução da glicina e aminoácidos excitatórios, evitando a produção de radicais de oxigênio, com aumento da peroxidase e conseqüente lesão aos lípides, p roteínas e DNA, assim como pela ativação microglial e despolarização isquêmica. Alguns estudos demonstraram que a inflamação potencializa a lesão isquêmica e que a hipotermia pode reduzir a infiltração leucocitária nas áreas isquêmicas. Para melhor elucidar os mecanismos pelos quais a hipotermia apresenta efeito neurop rotetor através da redução da inflamação, no processo isquêmico, escolhemos o método utilizando a indução de uma reação inflamatória com a utilização de uma substância com capacidade promover intensa reação inflamatória em encéfalos de ratos. Dois grupos de dez animais foram submetidos a um mesmo procedimento cirúrgico: a calota craniana foi parcialmente removida, a duramáter aberta e uma substância com potente efeito inflamatório (carragenina a 5\%) foi gotejada. A pele foi suturada e, para o g rupo com neuro p roteção, uma bolsa de gelo foi colocada, cobrindo toda a superfície craniana, de modo a manter a temperatura encefálica entre $29,5^{\circ} \mathrm{C}$ e $31^{\circ} \mathrm{C}$ durante 120 minutos. Três dias após, os animais foram sacrificados e os encéfalos examinados. 0 grupo protegido pela hipotermia apresentou considerável redução na infiltração leucocitária, demonstrando que a hipotermia pode apresentar função neuro protetora por meio de uma redução no processo inflamatório.

PALAVRAS-CHAVE: proteção cerebral, hipotermia encefálica, inflamação encefálica, hipotermia.

\footnotetext{
Universidade Federal de São Paulo, S. Paulo Brasil (UNIFESP): ${ }^{1}$ Professor Adjunto e Chefe da Disciplina de Neurocinurgia - Universidade Federal São Paulo - São Paulo, Brasil UNIFESP; ${ }^{2}$ Laboratório de Técnicas Neurocirúrgicas - Disciplina de Neurociru rgia - UNIFESP; ${ }^{3}$ P rofessor Titular Departamento de Farmacologia Celular - UNIFESP; ${ }^{4}$ r rofessor Adjunto de Neuropatologia Departamento de Patologia -UNIFESP.
}

Received 3 January 2005, received in final form 17 May 2005. Accepted 21 June 2005.

Dr. Mirto N. Prandini - Rua dos Crisântemos 117 - 040049-020 São Paulo SP - Brasil. E-mail: mnprandini@uol.com.br 
In 1956 Rosommoff ${ }^{1}$ reported that deep hypothermia $\left(23^{\circ} \mathrm{C}\right)$ reduced ischemic damage after experimental occlusion of the middle cerebral artery in dogs. Deep hypothermia became an adjuvant method for neuroprotection in cases where circulatory arrest in complex aneurysm surgery was necessary. However the detrimental effects of prolonged deep hypothermia including delayed recovery from anesthesia, acidosis, hemodynamic compromise, blood hypercoagulability, hypotension and myocardial arrhythmia have limited the use the technique ${ }^{2-4}$.Over the last 20 years a large number of studies have demonstrated that mild hypothermia $\left(31-33^{\circ} \mathrm{C}\right)$ can have the same neuroprotective effect provided by deep hypothermia in ischemic brain ${ }^{3,5-11}$. The mechanisms underlying this neuroprotection have been attributed to decrease in cerebral metabolic demand to oxygen and reduction of glycine and excitatory aminoacid (EAA) release. Glutamate release occurs 1-5 h after ischemic onset and mild hypothermia can be protective even if delayed by 2 hours $^{12}$. Corbett et al. ${ }^{10}$ demonstrated that delayed hypothermia reduces focal ischemic injury. Therefore, although reducing EAA release ${ }^{5}$ and glycine and glutamate release ${ }^{12}$, mild hypothermia can have other neuro$p$ rotective effects other than EEA, glutamate and glycine release. Even more, while neurop rotection by deep hypothermia can be explained by a decrease in cerebral blood flow and metabolic demand for oxygen, this by itself cannot fully explain the equally protection that has been shown when the temperature is lowered by only a few degrees ${ }^{13,14}$. A high d e gree of neuroprotection was conferred by postischemic cooling ( $2 \mathrm{~h}$ ) to $32^{\circ} \mathrm{C}$ which is virtually equivalent to that observed with intraischemic cooling at the same level in focal cerebral ischemia ${ }^{14}$.

It has been documented that inflammation contributes significantly to cerebral injury following ischemia7,15. Inflammatory cells presumably promote ischemic cell damage by microvascular occlusion. This may prolong and intensify the ischemic event ${ }^{16}$. Cytotoxic inflammatory reactions caused by microglial activation and blood-borne neutrophils have been implicated in the pathogenesis of ischemia/reperfusion brain injury 2,3,14,17-19. Neutrophils began to infiltrate into an infarct area soon after ischemia. Cytokine expression may be the earliest sign of the inflammatory response. Cytokines activate $\mathrm{microglia}$ and stimulate expression of endothelial adhesion leading to leukocyte infiltration. PMNL accumulation is maximal at $48-72 \mathrm{~h}$. Attenuation of the inflammatory response may be one of the mechanisms by which hypothermia reduces ischemic neuronal injury ${ }^{13,19,20}$.

Since it has been demonstrated that carrageenin is a highly reactive substance with inflammato ry properties ${ }^{21}$ and brain inflammation can be induced with its subarachnoidal injection in brains of mice ${ }^{22}$, in this study we aimed to demonstrate that mild hypothermia can have neuroprotective effects in brains of rats submitted to inflammatory injury by means of the use of carrageenin.

\section{METHOD}

Animal protocols were approved by the Federal University of S. Paulo animal's ethic board. Institutional guidelines were followed in all protocols. All animal experiments were conducted in accordance with the NIH guide for the care and use of laboratory animals (NIH publication 80-23). All efforts were made to minimize animal suffering, and only the smallest number of animals were used to generate reliable scientific data.

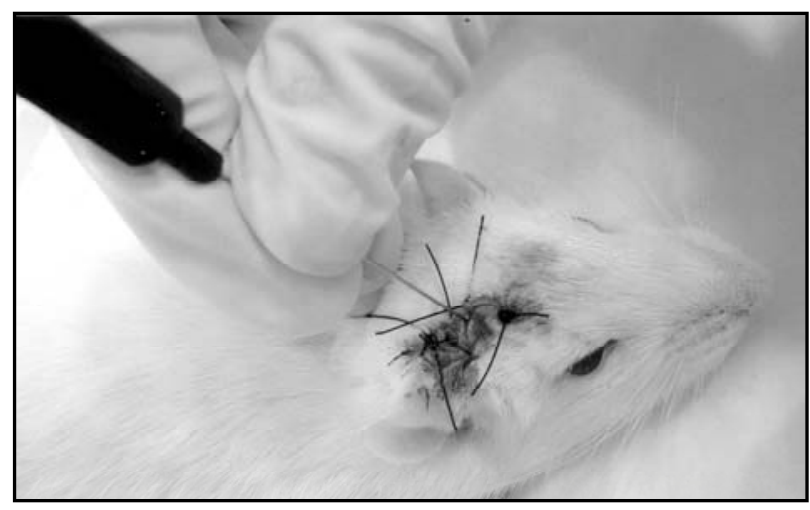

Fig 1. Line of incision of the skin.

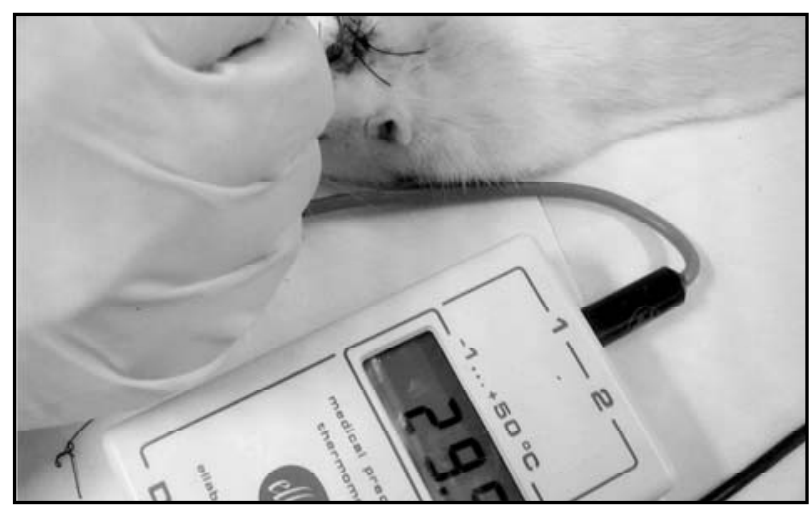

Fig 2. Brain temperature is observed. Probe is inserted $5 \mathrm{~mm}$ wi thin the brain parenchyma. 


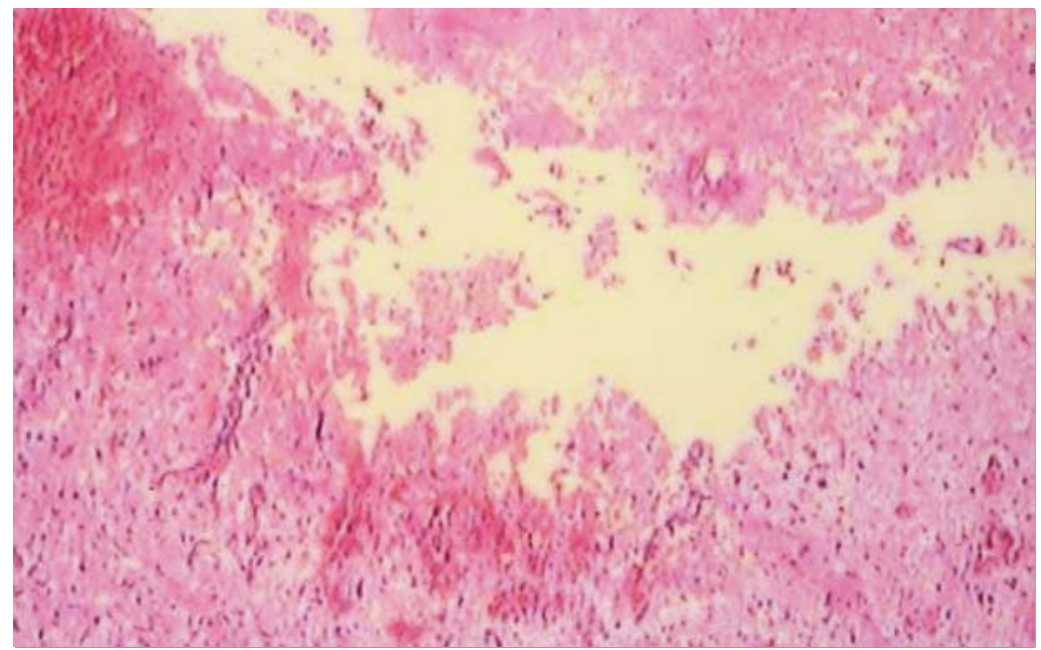

Fig 3. Brain of rat. Haematoxylin-eosin 200X. Slices obtained three days after $5 \%$ Carrageenin was dropped. No neuroprotection was performed. Small necrot ic area and marked inflammatory infiltration can be seen.

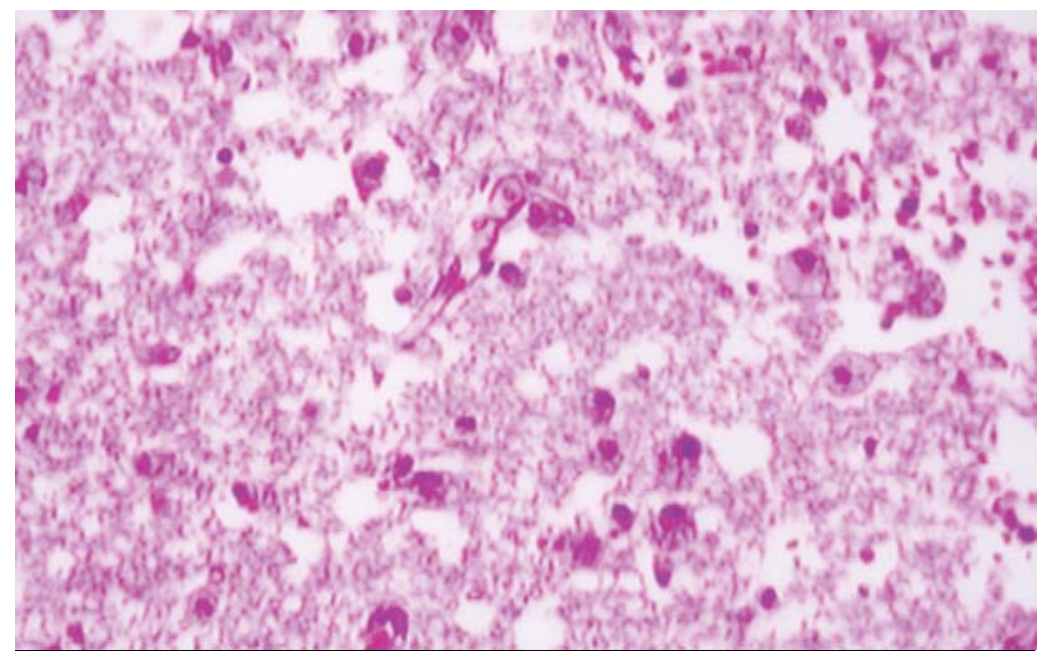

Fig 4. Brain of rat. Haematoxylin-eosin 200X. Slices obtained three days after $5 \%$ Carrageenin was dropped. Neuroprotection with hypothermia $\left(30^{\circ} \mathrm{C}\right)$ for 120 minutes. Macrophage infiltration with capillary proliferation can be seen.

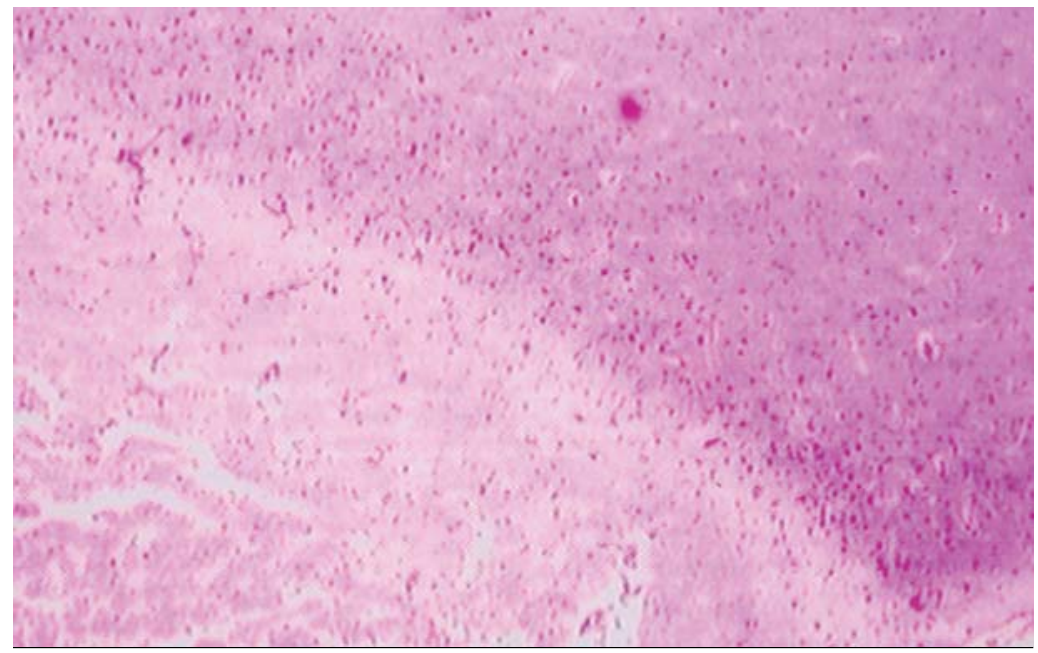

Fig 5. Brain of rat. Haema toxylin-eosin 40X. Slices obtained three days after $5 \%$ Carrageenin was dropped. Normal and pathological areas can be seen. 
Table 1. Total number of PMNL in group 2 and 3.

\begin{tabular}{|c|c|c|}
\hline \multicolumn{3}{|c|}{ PMNL/FIELD } \\
\hline \multicolumn{2}{|c|}{ GROUP 2} & \multirow{2}{*}{$\begin{array}{r}\text { GROUP } 3 \\
30\end{array}$} \\
\hline 1. & 98 & \\
\hline 2. & 88 & 38 \\
\hline 3. & 96 & 28 \\
\hline 4. & 72 & 24 \\
\hline 5. & 80 & 38 \\
\hline 6. & 72 & 32 \\
\hline 7. & 88 & 34 \\
\hline 8. & 72 & 40 \\
\hline 9. & 88 & 24 \\
\hline 10. & 96 & 32 \\
\hline
\end{tabular}

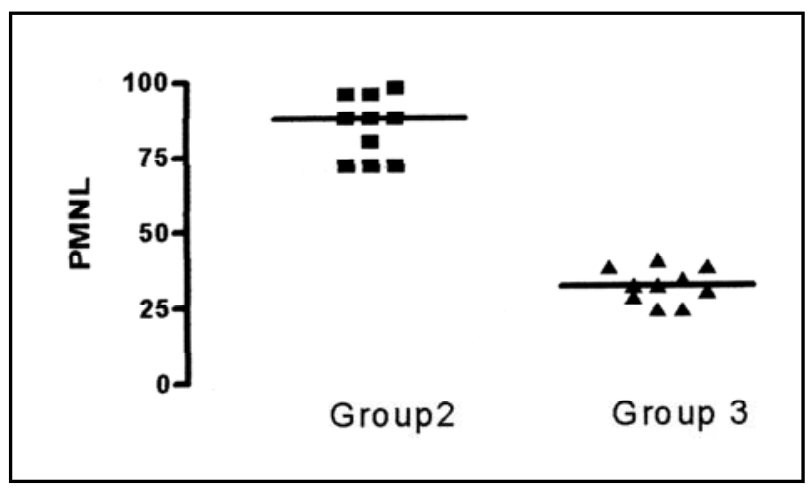

Fig 6. Scatter plot of PMNL accumulated after topical Carrage enin application.

Th ræ groups of ten Wistar E.PM rats weighing between $290 \mathrm{~g}$ and $330 \mathrm{~g}$ were studied.

G roup 1 - control group, Group 2 - received no protection by hypothermia and; Group 3 - received protection by hypothermia.

General anesthesia was given by means of IM injection of tiletamin chloridrate + zolazepan chloridrate in the proportion of $100 \mathrm{mg} / \mathrm{kg}$. The animals were placed in a specially designed table covered by an homeothermic blanket control unit (Harvard Apparatus Limited Cat 507079 Edenbridge Kent). The core temperature was maintained in $370 \mathrm{C}$ and was measured with a flexible fibber with the sensor tip placed into each animal's rectum (EIlab medical precision thermometer DM 852). The scalp incision measuring $18 \mathrm{~mm}$ was $C$ shaped $4 \mathrm{~mm}$ from the midline (Fig 1). The muscles and fascia were dissected from the cranium. Under an operating microscope a 10$12 \mathrm{~mm}$ burr hole was drilled and the dura was exposed. After the duramater had been incised, 2-3 drops of solution of $5 \%$ beta-carrageenin was topically dropped. The scalp was sutured with mononylon 3-0. In the group 3, (the one protected by hypothermia), an ice bag was pla- ced in order to cover the entire head. The ice bag was removed whenever the brain temperature dropped below $29,5^{\circ} \mathrm{C}$ and replaced when the temperature reached $31^{\circ} \mathrm{C}$. Brain temperature was measured with a needle probe placed subcutaneously inserted $5 \mathrm{~mm}$ into the brain parenchyma (Fig 2) (Ellab medical precision thermometer DM 852 ). The hypothermia was maintained for 120-130 minutes. The control group underwent the same surgical procedure but no inflammatory solution was dropped, nor was hypothermia performed.

After 3 days the animals were anesthetized and sacrificed. All bone of the superior part of the skull was withdrawn in order to permit the removal of the whole brain that was immediately fixed in formalin $10,0 \%$. The specimens were allowed to fix for 24 hours, and then embedded in paraffin.

Histopatological examination - Brains were sliced into $18-\mu \mathrm{m}$-thick coronal sections and stained with hematoxylin and eosin with magnification X40, X100, X200. High microscopy examination aimed to demonstrate the number of PMNL per field. Four fields were examined. Total number of cells was counted using original magnification $X 200$. Histopatological analysis revealed acute lymphocytic and macrocytic cell predominance; small areas of necrosis were also seen (Fig 3) in some cases without neuro $p$ rotection. Inflammatory infiltration was only seen in the specimens where carrageenin was dropped (Fig 4). In brain hemisphere that has not received carrageenin (Group 1) no significant sign of inflammatory reaction was identified. Normal and pathological areas can be seen in Figure 5. In group 2 and 3, the total number of PLNL is demonstrated in the Table 1.

Statisical analysis - Data are presented as means \pm standarddeviation. They were compared by analysis of variance followed by Mann Whitney Test. Data were considered different at $p<0.5$ (Fig 6).

\section{DISCUSSION}

Rosommoff ${ }^{1}$ first reported that deep hypothermia reduced ischemic damage after experimental occlusion of the MCA in dogs. The use of deep hypothermia has been limited because of several undesirable side effects including acidosis, blood hypercoagulability, delayed recovery from anesthesia, hemodynamic compromise, myocardial arrhythmia and hypotension ${ }^{2-4}$. More recently several studies have shown that mild hypothermia can have the same neuroprotective effect in ischemic models using rodents, cats and dogs and the severe limitations associated with deep hypothermia can be avoided ${ }^{5-10}$. Prandini et al. ${ }^{11}$ have demonstrated that mild hypothermia, locally produced in rabbit's brains, can redu- 
ce infarct size in cases of ischemia produced by coagulation of the middle cerebral artery.

It has been a matter of debate the mechanisms implicated in the neuro $p$ rotective effects of hypothermia. A large number of studies have shown that the mechanisms of neuro p rotection conferred by moderate hypothermia are multifactorial5,14-16. Mechanisms of injury that are ameliorated by hypothe rmia and exaggerated by moderate hyperthermia include, oxygen radical production, with peroxidase damage to lipids, proteins and DNA, microglial activation and ischemic depolarizat i o $n^{5,14-16}$, decrease in cerebral metabolic demand for oxygen and reduction of EEA and glycerin release ${ }^{12}$ also cannot fully account for the neuroprotective effect of hypothermia. Recent studies have demonstrated that inflammation is a major determinant of neural death following ischemia ${ }^{15,17-19,24}$. Focal ischemia and reperfusion of the neocortex elicit a substantial cell-mediated inflammatory response and produced cell infarction ${ }^{23-25}$. Cellular inflammation is initiated by ischemia at the blood microvascular endothelial cell interface ${ }^{14}$.

Polymorphonuclear leukocytes are early part i cipants in the cerebral microvascular response to focal ischemia ${ }^{16,18}$. The presence of PMNL in occluded microvessels within 60 minutes after MCA occlusion in baboons has been demonstrated ${ }^{15}$. Developing infarction was accompanied by accumulation of inflammatory cells of both intrinsic (microglia) and extrinsic (macroglia) origin ${ }^{25}$. Treatment with antipyretic and antiinflammatory drug dipyrone delays neuronal damage in the rat hippocampus, cortex and striatum ${ }^{26}$. Anti-adhesion molecule antibodies selectively reduces apoptosis in transient middle cerebral art e ry in rat brain ${ }^{27}$. Toyoda et al. ${ }^{24}$ demonstrated that intraischemic hypothermia attenuates neutrophil infiltration in the rat neocortex after focal ischemia-reperfusion-injuny Kawai et al. ${ }^{13}$ have demonstrated that ischemic brain damage can be reduced with delayed hypothermia and prolonged postischemic hypothermia in a focal model of transient cerebral ischemia in rats. One of the mechanisms by which hypothermia reduces ischemic neuronal injury is by attenuating the inflammatory response ${ }^{13,19}$. Intraischemic hypothermia reduced the volume of infarction by $59 \%$ compared with the normothermic animals. Since the accumulation of PMNL is maximal at $48-72 \mathrm{~h}$ after ischemic insult, our specimens were obtained only $72 \mathrm{~h}$ after the inflammatory reaction had begun.
While several studies have begun to elucidate the contribution of the inflammatory response to cerebral ischemic injury, the effect of hypothermia on the inflammatory response is still unclear, 10,15,17-19.

Ca rrageenin was used in our experiments because for more than 50 years it has been considered as one of the best drugs to produce inflammatory activity ${ }^{21}$ and its inflammatory properties when subarachnoidally injected have been demonstrat$\mathrm{ed}^{22}$. Our results indicate that mild hypothermia effectively reduced the leukocyte infiltration on brains of rats subjected to this potent inflammatory substance. This could explain one additional mechanism of protection provided by mild hypothermia.

\section{REFERENCES}

1. Rosomoff HL. Hypothermia and cerebral vascular lesions 1; experimental interruption of the middle cerebral artery during hypothermia. J Neurosurg 1956;13:244-255.

2. Guegan Y, Scarabin JM, LeGilcher C, Guillion I. Extracorporeal circulation with deep hypothermia and circulatory arrest in the treatment of aneurysm. Surg Neurol 1985;24:441-448.

3. Goto Y, Kassell NF, Hiramatsu K, Soleau SW, Lee KS. Effects of intraischemic hypothermia on cerebral damage in a model of reversible focal ischemia. Neurosurgery 1993;32:980-984.

4. Steen PA, Midle JH, Michenfelder JD. The detrimental effects of prolonged hypothermia and rewarming in the dog. Anesthesiology 1980; 52:224-230.

5. Busto R, Dietrich WD, Globus MY, Ginsberg MD. The importance of brain temperature in cerebral ischemic injury. Stroke 1989;20:1113-1114.

6. BakerCJ, Onesti ST, Barth KN, Prestigiacomo CJ, Solomon RA. Hypothermic protection following middle cerebral artery occlusion in the rat. Surg Neurol 1991;36:175-180.

7. Connolly ES, Winf reeCJ, Springer TA, et al. Cerebral protection in homozygous null ICAM-I mice after middle cerebral artery occlusion: role of neutrophil adhesion in the pathogenesis of stroke. J Clin Invest1996;97:209-216.

8. Karibe H, Zarow GJ, Graham SH, Weinstein PR. Mild intraischemic hypothermia reduces postischemic hyperperfusion, delayed postischemic hypoperfusion, blood-brain barrier disruption, brain edema, and neuronal damage volume after temporary focal cerebral ischemia in rats. J Cer Blood Flow Metab 1994;14:620-627.

9. Makarian GZ, Lee JH, Stein DJ, Hong SC. Mild hypothermia: therapeutic window after experimental cerebral ischemia. Neurosurgery 1996;38:542-551

10. Corbett D, Hamilton M, Colbourne F.Persistent neuroprotection with prolonged postischemic hypothermia in adult rats subjected to transient middle cerebral artery occlusion. Exp Neurol 2000;163:200-206.

11. Prandini MN, Lacanna SN, Valente PR, Stavale JN. Regional mild hypothermia in the protection of the ischemic brain Acta Cir Bras 2002; 17:232-235.

12. Huang F, Zhou LF, Yang GY. Effects of mild hypothermia on the release of regional glutamate and glycine during extended transient focal cerebral ischemia in rats. Neurochem Res 1998;23:991-996.

13. Kawai N, Okauchi M, Morisaki K, NagaoS. Effects of delayed intraischemic and postischemic hypothermia on a focal model of transient cerebral ischemia in rats Stroke 2000;31:1982-1989.

14. Colbourne F, Li H, Buchan AM. Indefatigable CAI sector neuroprotection with mild hypothermia induced 6 hours after severe forebrain ischemia in rats. J Cer Blood Flow Metab1999;19:742-749.

15. Del Zoppo GJ, Schmid-Schônbein GW, Mori E, Copeland BR, Chang $\mathrm{CM}$. Polymorphonuclear leukocytes occlude capillaries following middle cerebral artery occlusion and reperfusion in baboons. Stroke 1991; 22:1276-1283. 
16. Garcia JH, Liu KF, Yoshida Y, Lian, Chen S, del Zoppo GJ. Influx of leukocytes and platlets: relevance to ischemic brain injury. Cerebrovasc Brain Metab Rev 1994;4:189-225.

17. Huh PW, Belayev L, Zhao W, Koch S, Busto R, Ginsberg MD. Comparative neurop rotective efficacy of prolonged moderate intraischemic and postischemic hypothermia in focal cerebral ischemia. J Neurosurg 2000;92:91-99.

18. Hernandez LA, Gnsham MB, Twohlg B, Arfors KE, Harlan JM, Granger DN. Role of neutrophils in ischemia-reperfusion induced microvascular injury. Am J Physiol. 1987;253:699-703.

19. Kochanek PM, Hallenbeck JM. Polymorphonuclear leukocytes and monocytes / macrophages in the pathogenesis of cerebral ischemia and stroke. Stroke 1992;23:1367-1379.

20. Wang GJ, Deng CM, Maier GH, Sun GH, Yenaryy MA. Mild hypothermia reduces ICAM-expression, neutrophil infiltration and microglia/monocyte accumulation following experimental stroke. Neuroscience 2002;114:1081-1090.

21. Smith DB, Cook WH, Neal JL. Physical studies on carrageenin and carrageenin fractions. Arch Biochem 1954;53:192-204.
22. S p rumont $\mathrm{P}$, Kaelin-Lang A, Van Lierde S, Maenhaut W, De Reuck J. Effect of neurot ropin on cerebral edema, calcium and other elements in mice subarachnoidally injected with carrageenin. Eur J Pharmacol 1995;274:95-99.

23. Matsuo Y, Onodera H, Shozuhara H, et al. Role of cell adhesion molecules in brain injury after transient middle cerebral artery occlusion the rat. Brain Res 1994;656:344-352.

24. Toyoda T, Suzuki S, Kassel NF, Lee KS. Intraischemic hypothermia attenuates neutrophil infiltration in the rat neocortex after focal ischemia-reperfusion injury. Neurosurgery. 1996;39:1200-1204.

25. Kato H, Kogure K, Liu XH, et al. Prog ressive expression of immunomolecules on activated microglia and invading leukocytes following focal cerebral ischemia in the rat. Brain Res 1996;734:203-212.

26. Coimbra C, Drake M, Boris-Möller F, Wieloch T. Long-lasting neurop rotective effect of postischemic hypothermia and treatment with an anti-inflammatory/ antipyretic drug. Stroke 1996;27:1578-1585.

27. Chopp M, Li Y, Jiang N, Zhang R, Prostak J. Antibodies against adhesion molecules reduce apoptosis after transient middle cerebral artery occlusion in rat brain. J Cer Blood Flow Metab 1996;16:578-584. 